JPPUMA: Jurnal Ilmu Pemerintahan dan Sosial Politik UMA (Journal of Governance and Political Social UMA),

8 (1) (2020): 57-67, DOI: https://doi.org/10.31289/ippuma.v8i1.3393

JPPUMA: Jurnal Ilmu Pemerintahan dan Sosial Politik UMA

(Journal of Governance and Political Social UMA)

Available online http://ojs.uma.ac.id/index.php/jppuma

\title{
Effects of Mass Media and Digital Media Internet on Young Voter Participation
}

\author{
Christina Natalia Jesica1)\#, R. Widya S. Sumadinata2) \& Caroline Paskarina ${ }^{3)}$ \\ 1) Political Science Postgraduate Program, Universitas Padjadjaran, Indonesia \\ 2) Department of International Relations, Faculty of Social and Political Sciences, \\ Universitas Padjadjaran, Indonesia \\ 3) Department of International Relations, Faculty of Social and Political Sciences, \\ Universitas Padjadjaran, Indonesia
}

Recieved: January 21, 2020; Accepted: March 12, 2020; Published: June 01, 2020

\begin{abstract}
Voter participation indicates the success or failure of a general election. People of Bandung City, who have been characterized as an urban society, openly accept mass media as an information channel and the internet as a form of information technology development. In terms of quantity, young voters have potential as a major group of voters in the General Election. The number of young voters in Bandung City achieves 29.6\% of the voters on the list (Daftar Pemilih Tetap/DPT or List of Voters) in the Election of Mayor and Deputy Mayor of Bandung in 2018. The lives of the young generation are closely related to the development of media. In this context, therefore, the authors researched to find out if there is a significant effect of print media, electronic media, and internet media on the participation of young voters in Bandung. This article is written based on a survey of 100 respondents aged 17-year-old (married/had been married) up to 30-year-old, who is registered on the List of Voters or DPT in the Election of Mayor and Deputy Mayor of Bandung in 2018. This research uses an instrument named The Ordinal Scale whose validity and reliability have been proven. The research applies a technique Multiple Linear Regression to analyze data, as well as in examining hypothesis. The research findings reveal that print media and electronic media did not have a significant effect on young voters but did the internet media have a necessary effect on the young voters.
\end{abstract}

Keywords: Voter Participation, Young Voter, Media, Effect

How to Cite: Jesica, C.N. Sumadinata, R.W.S. \& Paskarina, C. (2020). Pengaruh Efek Media Massa dan Media Internet terhadap Tingkat Partisipasi Pemilih Muda di Kota Bandung. JPPUMA: Jurnal Ilmu Pemerintahan dan Sosial Politik UMA (Journal of Governance and Political Social UMA), 6 (2): 106-111

*Corresponding author:

E-mail: t2n.cnj@gmail.com
ISSN 2549-1660 (Print)

ISSN 2550-1305 (Online) 



\section{INTRODUCTION}

Public participation in voting is one of the indicators in assessing the success of the election, including in Indonesia. The decline of voter participation, therefore, has a political impact on the legitimacy of the result of the election.

In the implementation of the General Election in Indonesia, most regions in Indonesia could not achieve the desired participation target. Specifically, it can be seen since the implementation of the local elections (regional head elections) held simultaneously in 2015, in which some of the Indonesian regions obtained the level of participation that is far below the expected target. General Election Commission (KPU) has targeted voter participation in the simultaneous local election inn 2015 and 2017 to achieve 77.5 percent. Nevertheless, it could be realized only, consecutively, 69.20 percent, and 74.5 percent (KPU, 2017.

Bandung City is the capital of the Province of West Java. It has the highest number of voters in the 2019 Elections. The Official Voter List in West Java Province noted that there are 33,276,905 voters, while the voters in the City of Bandung are 1,739,927 (KPU of West Java Province, 2019). Interestingly, the candidates in the 2019 Presidential Election contested for votes in the West Java Province. It is assumed that the victory in West Java is considered to give an advantage in the 2019 Presidential Election.

For contestants in the General Election, mapping the age range of voters is also part of the strategy to win the contestation. Especially due to the young voters form a significant number in the voter list. According to Law No. 40 of 2009 concerning Youth, it states that youth are Indonesian citizens between the age of sixteen and thirty years. Whereas, according to KPU Regulation No. 2 of 2017 concerning the Updating Data and Preparation of Voter Lists in the Election of
Governors and Deputy Governors, Regents and Deputy Regents, and/or Mayor and Deputy Mayor, the requirements to become voters are at minimum aged seventeen years or already have marital status. It can be said that young voters are voters aged between seventeen and thirty of those who are married. According to the Voters List, the number of young voters in Bandung City in the Election of Mayor and Deputy Mayor in 2018 was 491,661 voters, which was $29.6 \%$ of the total of $1,659,017$ voters (KPU of West Java Province, 2018).

In the General Election of Bandung Mayor and Deputy Mayor on 27 June 2018, the young voters have been defined as those who were s referred to were voters born between June 27, 1988, to June 27, 2001. Based on the grouping of generations (KPPPA \& BPS, 2018), this age group is to be categorized in the millennial generation or Generation Y. The millennial generation is the age cohort who are born between 1980 and 2000 . In quantity, the millennial generation in West Java Province is the largest in Indonesia, which amounts to 16.5 million (KPPPA \& BPS, 2018).

According to Rush \& Althoff (2013), the concept of participation is closely related to socialization, in which the participation is a partial dependent variable of socialization and communication. It, therefore, the distribution of political information is very effective in voters' participation to vote for a candidate in General Election.

Loina Lalolo Krina Perangin-angin, who researched the 2014 Election in the city of Bandung (in Perangin-angin \& Zainal, 2018), indicates that there is an apathy of the young voters in political participation. The research reveals a correlation between the use of social media and political participation, though the correlation is small. This is in line with Steven H. Chaffee et al. (Nimmo, 2006) research that shows that the relationship between media exposure and public 
participation in political campaigns or decision-making is relatively weak.

The Indonesian Ministry of Information and Communication in collaboration with UNICEF (2014), concluded in a survey that 98 percent of the children and adolescents knew about the internet and 79.5 of them were internet users.

Febriana, HH, Nailufar, FD, \& Subandi, H. (2015) in their research about the influence of Mass Media on Labor and Civil Servants' votes in Malang City in the 2014 Presidential Election, conclude that the mass media only provides the information related to the 2014 presidential election. However, it does not affect the Labor and Civil Servants in deciding to give votes for a certain candidate.

In urban society, electronic media such as radio, or print media like newspapers and magazines can be used to convey political messages (Firmanzah, 2012). Likewise, the people of Bandung City who have the characteristics of urban society openly accept the mass media as an information channel. It is also including the internet media in the development of information technology. With the characteristics of an urban community, young voters in the city of Bandung are very likely to be exposed to political information through various media that affect their participation in General Election.

The mass media function as an intermediary of the distribution of information in the process of political socialization. The factors that are considered to influence political participation of the younger generation are the exposure to knowledge, family ties, and also the media (Putra, Susanti, Yusari, Silitonga, \& Amrie: 2014). This thesis ensures that there is an important relationship between young people and the media. Moreover, the mass media has developed further, especially among the younger generation. Therefore, the authors intend to manage a study on the effects of mass media, especially the effect of print media, electronic media, and the internet media on the participation of young voters in the 2018 Election of Mayor and Deputy Mayor of Bandung.

In this study, the author brings forward the main question. Is there a significant effect of print media, electronic media, and the internet media on the participation of young voters in Bandung? To understand the effects of print media, electronic media, and the internet media on the participation of young voters, the author approached the effect of mass media messages on changes in the audience. The changes that occur due to mass media, according to Steven H. Chaffe (Ardianto, Komala, \& Karlinah, 2007), consist of cognitive effects, affective effects, and behavioral effects.

The effects of the mass media are used as indicators in this research. The author measures the effects of the media based on indicators of the effect of messages on the audience. Firstly, the cognitive effects. Cognitive effects are indicated by the increase of information obtained from print media, electronic media, and internet media. Moreover, there is also an understanding of information obtained from print media, electronic media, and internet media. Secondly, the affective effects. Affective effects are indicated by the feelings in response to messages received from print media, electronic media, and internet media. Thirdly, behavioral effects. Behavioral effects are indicated by the attitudes, actions, and activities that have been carried out in responses after the communication process.

In terms of voter participation, the author refers to the measurement made according to International IDEA in the Voter Turnout Trend Around the World (2016). The author divides into 2 two categories. First, the use of votes by voters to vote at the time of the election. Eligible 
citizens have the right to vote in elections. Second, awareness of political rights. The voters' votes are potential to be used as a form of political aspiration that becomes a concern of some groups of the citizen. A factor that affects public participation is political awareness (Surbakti, 2013).

The effects of mass media and the effects of the internet media are presented in Figure 1. The effects are described as influencing the participation of young voters. By the effects means cognitive, affective, and behavioral. The mass media in this study consist of print media, such as newspapers and magazines, electronic media such as radio and television, and the internet media in the forms of websites, news sites or portals, Blogs, YouTube, Facebook, Twitter, LINE, WhatsApp (WA), and Instagram, and the like.

\begin{tabular}{|c|c|}
\hline $\begin{array}{l}\text { The effects of } \\
\text { mass media and } \\
\text { the internet. } \\
\text { - Cognitive } \\
\text { - Affective } \\
\text { - Behavioral }\end{array}$ & $\begin{array}{c}\text { Participation } \\
\text { of young } \\
\text { voters } \\
\text { (Y) }\end{array}$ \\
\hline (X) & \\
\hline
\end{tabular}

Figure 1. The effects of mass media on the participation of young voters

\section{RESEARCH METHOD}

The focus of this study is young voters. This study designs survey methods to minimize the subjectivity of researchers. Fairly large population coverage and its spread in the city of Bandung will be more easily reached by sampling. The author applies this sampling as part of the survey procedure. This study applies the quantitative approach to measure the trend of the effects of mass media and internet media on the participation of young voters in the 2018 Election of Mayor and Deputy Mayor of Bandung.

This study defines the population as young voters in Bandung City. It includes Bandung residents who were registered in the List of Voters on the Election of Mayor and Deputy Mayor of Bandung in 2018. The voters are those who are between the age of seventeen and thirty years or those who have/had married. By this definition, there as many as 491,661 young voters. The author refers to the Slovin formula to get the minimum sample, which is calculated with a critical value of $10 \%$, then 100 respondents are obtained. The sample was taken randomly and spread out in 10 districts that have been selected systematically. These sub-districts are namely, Regol, Cibeunying Kidul, Bojongloa Kidul, Antapani, Rancasari, Ujung Berung, Cinambo, Coblong, Andir, and Cidadap.

Primary data have been collected by distributing questionnaires to 100 respondents. Secondary data have been collected from the KPU of the City of Bandung, which are official documents of the Election of Mayor and Deputy Mayor of Bandung in 2018. The other secondary sources are KPU Regulations, published sources in books and on the internet.

The research instrument uses an ordinal scale with six categories of responses mentioned in the research questionnaire. Before conducting the research, the instrument has first been tested the validity and reliability of 30 people who were part of the study population. The use of the scales is expected to avoid answers that are neutral or contain doubts from respondents. The research data in the form of Ordinal data have been transformed to an interval scale using the Method of Successive Interval (MSI) as required for calculation analysis.

This study has an independent variable, namely "the effect of internet media (X)", and a dependent variable, which is "participation of young voters (Y)". The author uses a level of significance in making decisions to reject or accept the hypothesis in this study, which is equal to $\alpha=5 \%$. 
Data analysis has been managed by simple descriptive statistics. The author uses a tool for processing data by using SPSS 22.0 software (Statistical Package for Social Science) and Microsoft Excel. Moreover, the authors conducted a classic assumption test, namely the multicollinearity test, homoscedasticity test, and normality test.

Furthermore, it is necessary to understand the relationship between the independent variable and the dependent variable grasp the effect of independent variables on the dependent variable. The author calculates through the Pearson Correlation to understand the close relationship of the print media, electronic media, and the internet media variables on young voter participation. Besides, Table 1 below describes the magnitude of the correlation coefficient, as following.

Tabel 1. Interpretation of correlation coefficient

\begin{tabular}{ll}
\hline Interval Coefficient & Level of relationship \\
\hline $0,00-0,199$ & Lowest \\
$0,20-0,399$ & Low \\
$0,40-0,599$ & Middle \\
$0,60-0,799$ & Strength \\
$0,80-1,000$ & Very strenght \\
\hline
\end{tabular}

Source: Sugiyono, 2013

If all the classical assumption tests have been met, the author can perform multiple regression analysis calculations. The technique of multiple regression analysis is to determine the score of participation of young voters (the dependent variable) based on the prediction towards the effects of print media, electronic media, and the internet media (independent variables).

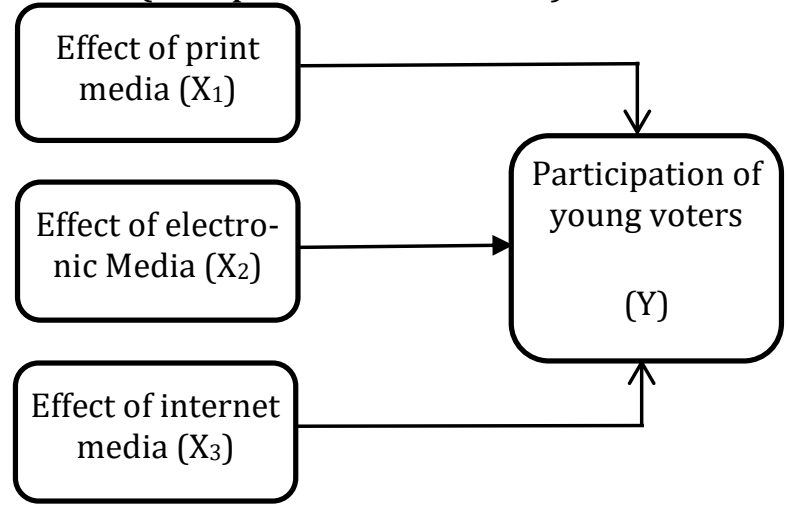

Figure 2. Multiple regression model
The above figure shows that the independent variables are the effects of print media, electronic media, and internet media. While the dependent variable is the participation of young voters.

Hypothesis testing has been done by the T-test to partially determine the significance of the effect of mass media and internet media on the participation of young voters. The grade of independence (n-k-1) or $100-3-1=96$ so it obtains the number of table 1,985 so the requirements for making decisions are as following:

- If tgrade $\geq$ ttable $(1,985), \mathrm{H}_{0}$ is on the position of denial, meaning that $\mathrm{H}_{1}$ is accepted or having an effect.

- If $t_{\text {grade }}<t_{\text {table }}(1,985), H_{0}$ is on the position of acceptance, meaning $\mathrm{H}_{1}$ is denied or having no effect.

\section{RESULT AND DISCUSSION}

The majority of respondents of this research those who are at the age of 22 to 25-year-old, which form 42 percent of the total respondents. It can be estimated that generally, respondents have participated in more than one General Election. By 80 percent of the respondents have voted more than once until the 2018 election.

The result of this research shows that the frequency of respondents in reading newspapers/ magazines obtains 60 percent of the respondents, who read newspapers or magazines 0-2 days a week. Whereas, by 56 percent of the respondents listen to the radio or watch television more than five days a week. This means that, in general, respondents' interest in reading is very low, but the level of interest in electronic media such as radio and television is quite high. Regarding the internet media, there are three internet media that are most frequently accessed by the respondents, namely; WhatsApp (WA), Instagram, and Youtube.

To enrich the discussion, the author calculates the score of the respondent's response on the given statement, which is based on the scale used that is ranged from 1 to 6 . The respondent's response is the 
respondent's perception of the approval of the questionnaire's statement. The result of the scoring is presented in Table 2 as follows.

Tabel 2. Perception of the respondents

\begin{tabular}{|l|l|l|l|}
\hline $\begin{array}{l}\text { Media } \\
\text { Effects }\end{array}$ & $\begin{array}{l}\text { Print } \\
\text { media }\end{array}$ & $\begin{array}{l}\text { Electronic } \\
\text { media }\end{array}$ & $\begin{array}{l}\text { Internet } \\
\text { media }\end{array}$ \\
\hline Cognitive & $79.3 \%$ & $83.05 \%$ & $84.6 \%$ \\
\hline Affective & $73.8 \%$ & $78.17 \%$ & $81.5 \%$ \\
\hline Behavioral & $74.38 \%$ & $77.47 \%$ & $80.3 \%$ \\
\hline
\end{tabular}

Source: the result of primary data management, 2019

The above table shows that, in general, the respondents gave the highest score of responses tot he given statements containing cognitive effects. The author interprets that newspapers and magazines, radio and television, as well as internet media, have the highest effect of cognitive aspect compared to the affective and behavioral aspects. This is consistent with what Steven H. Chaffee states (Nimmo
2006) that there is a positive relationship between exposure to television and newspapers to the amount of information regarding politics that young people have.

The effect of cognitivecommunication at the level of thought is the most easily arising effect. For example, the increase of information and the increase of understanding of the information about the Election of Mayor and Deputy Mayor of Bandung in 2018 are due to newspapers and magazines, radio and television, and the internet media.

The result of the calculation of the correlation coefficient between the independent variables (print media, electronic media, and the internet media) and the dependent variable (the participation of young voters) based on SPSS 22.0 software output is displayed in the following table.

Table 3. Correlation coefficient

\begin{tabular}{llllll}
\hline & & $\mathrm{X} 1$ & $\mathrm{X} 2$ & $\mathrm{X} 3$ & $\mathrm{Y}$ \\
\hline $\mathrm{X} 1$ & Pearson Correlation & 1 & $.488^{* *}$ & $.348^{* *}$ &. $\mathbf{1 7 0}$ \\
& Sig. (2-tailed) & & .000 & .000 & .091 \\
& $\mathrm{~N}$ & 100 & 100 & 100 & 100 \\
\hline $\mathrm{X} 2$ & Pearson Correlation & $.488^{* *}$ & 1 & $.567^{* *}$ &. $\mathbf{3 6 0}^{* *}$ \\
& Sig. (2-tailed) & .000 & & .000 & .000 \\
& $\mathrm{~N}$ & 100 & 100 & 100 & 100 \\
\hline $\mathrm{X} 3$ & Pearson Correlation & $.348^{* *}$ & $.567^{* *}$ & 1 & .000 \\
& Sig. (2-tailed) & .000 & .000 & & 100 \\
& N & 100 & 100 & 100 & 1 \\
\hline Y & Pearson Correlation & .170 & $.360^{* *}$ & $.517^{* *}$ & .000 \\
& Sig. (2-tailed) & .091 & .000 & 100 & 100 \\
& N & 100 & 100 & & .000 \\
\hline
\end{tabular}

**. Correlation is significant at the 0.01 level (2-tailed).

Source: Primary data management, 2019

The above table shows the correlation coefficient values on the effects of print media, electronic media, and the internet media with young voter participation. The interpretation of the above scores is as follows. First, the correlation coefficient of print media's effects with young voter participation is 0.170 with an insignificant relationship, as the value sig (0.091) is above 0.05. Second, the correlation coefficient of electronic media's effects with young voter participation is 0.360 meaning "low" relationship with a significant relationship, as the sig $(0,000)$ value is below 0.05 . Third, the correlation coefficient of the effect of the internet media with young voter participation is 0.517 meaning "medium" relationship with a significant relationship as the sig $(0,000)$ value is below 0.05 . 


\section{Multiple Linear Regression Analysis}

All the classical assumption tests have been met so the multiple regression analysis can be performed. In this study, the multiple regression calculation was used to analyze the young voter participation score based on the precision of prediction on the effects of print media, electronic media, and the internet media.

The multiple linear regression analysis is formulated in the following equation:
With:

$\mathrm{Y}$ : Participation of young voter

$\mathrm{X}_{1} \quad$ : Effect of print media

$\mathrm{X}_{2} \quad$ : Effect of electronic media

$\mathrm{X}_{3} \quad$ : Effect of internet media

a : Constanta

$\beta_{1}, \beta_{2}$, dan $\beta_{3}$ : regression coefficient

$\varepsilon \quad$ : error model/other variables that are not studied

The result of data processing through SPSS 22.0 Software for multiple regression analysis is displayed in the following table.

$Y=a+\beta_{1} X_{1}+\beta_{2} X_{2}+\beta_{3} X_{3}+\varepsilon$

Table 4. Analysis of multiple regression

Coefficients

\begin{tabular}{clllll}
\hline \multirow{2}{*}{ Model } & \multicolumn{2}{l}{ Unstandardized Coefficients } & Standardized Coefficient & $\mathrm{t}$ & \multirow{2}{*}{ Sig. } \\
\cline { 2 - 5 } & $\mathrm{B}$ & Std. Error & Beta & & \\
\hline (Constant) & 1.577 & .359 & & 4.396 & .000 \\
\hline $1 \mathrm{X} 1$ & -.053 & .102 & -.051 & -.513 & .609 \\
\hline $\mathrm{X} 2$ & .110 & .104 & .120 & 1.054 & .295 \\
\hline $\mathrm{X} 3$ & .435 & .099 & .467 & 4.413 & .000
\end{tabular}

a. Dependent Variable: Y

Source: primary data management, 2019

The above calculation (displayed in Table 4), have been made on the basis of the multiple linear regression as following equation: $Y=1,577-0,053 X_{1}+\mathbf{0 , 1 1 0}$ $X_{2}+0,435 X_{3}+\varepsilon$

The grade of the regression coefficient on the independent variables illustrates, if the independent variable is estimated to increase by one unit and the value of the other independent variables is estimated to be constant or equal to zero, then the value of the dependent variable is expected to increase or decrease following the regression coefficient mark of the independent variable.

The effect of print media on the participation of the young voters

The hypotheses that are tested are:

$\mathrm{H}_{0}$ : There is no significant effect of the print media on the participation of young voters in the city of Bandung.

$\mathrm{H}_{1}$ : There is a significant effect of the print media on the participation of young voters in the city of Bandung.
The relationship that occurs between the effect of print media and young voter participation can only be applied to the tested samples. In other words, the effect of print media has no relationship with young voter participation in the City of Bandung.

The analysis of the multiple linear regression shows that there is a unidirectional relationship between the effect of Print Media (X1) to the Young Voter Participation (Y), where $\beta 1$ is $-0,053$. This indicates that the communication effect of newspapers and magazines does not contribute to the increase in the participation of young voters in the city of Bandung in 2018. Conversely, there are irregularities in which the increase of the use of print media as a source of information is not followed by the increase of the participation of young voters.

Hypothesis testing The test is based on Table 4. It is tgrade $(-0.513)<t_{\text {table }}$ $(1,985)$. With a confidence level of 95 percent $(\alpha=0,05)$. It is decided that $\mathrm{H}_{0}$ is 
accepted and $\mathrm{H}_{1}$ is rejected. Where $\mathrm{H}_{0}$ : There is no significant effect of the print media on the participation of young voters in the city of Bandung.

The above analysis on the effects of print media is corresponding with what Steven H. Chaffee et al. (Nimmo, 2006) states, that the relationship between media exposure and participation in political campaigns or decision-making is relatively weak. Moreover, this study reveals that the effect of print media is not related and does not have a significant influence on the participation of young voters in the city of Bandung.

In this respect, the possible causes that the author can explain regarding the absence of significant influence from newspapers and magazines on the participation of young voters are namely: 1) The interest of young voters in reading newspapers and magazines is very low, as the majority of respondents (approximately 60 percent) have a reading frequency in the range of 0-2 days a week; 2) mass media is very progressive in following the developments of the era, so the conventional mass media has decreased ist attractiveness; 3) Newspapers and magazines have been replaced by the online news sources in the internet media platform.

The effect of electronic media on the participation of young voters

The hypotheses that are tested are:

$\mathrm{H}_{0}$ : There are no significant effects of electronic media on the participation of young voters in the city of Bandung.

$\mathrm{H}_{1}$ : There are significant effects of electronic media on the participation of young voters in the city of Bandung.

The analysis of the multiple linear regression reveals that there is a direct relationship between the effects of electronic media (X2) on Young Voter Participation (Y), where $\beta 2$ is 0.110 . That means that the use of radio and television contributes to the increase in the participation of young voters in the city of Bandung. However, the correlation indicates that the Electronic Media Effect has a "low" relationship with the participation of young voters in the city of Bandung.

Whereas, the test of the hypothesis $t$ test on the above shows that tgrade (1.054) $<$ table (1.985). With a confidence level of 95 percent $=(\alpha=0.05)$, it has been decided that $\mathrm{H}_{0}$ was accepted, and $\mathrm{H}_{0}$ was rejected. Where $\mathrm{H}_{0}$ : There is no significant effect between the electronic media on the participation of young voters in the city of Bandung.

In this respect, the possible causes that the author can explain regarding the absence of a significant effect of the electronic media on the participation of young voters, include: 1) Television and radio broadcasts can be enjoyed through the internet media. As many as 50 percents of the internet users in Indonesia are streaming TV content (Seven Ads. 2019); 2) The content in the internet media is more diverse so it is more interesting than television or radio.

\section{The effect of the internet media on the participation of young voters}

The hypotheses that are tested are:

$\mathrm{H}_{0}$ : There are no significant effects between the internet media on the participation of young voters in the city of Bandung.

$\mathrm{H}_{1}$ : There are significant effects of the internet media on the participation of young voters in the city of Bandung.

The correlation calculations indicate that the Internet Media Effect has a "moderate" relationship with the participation of young voters in the city of Bandung. While the results of the multiple linear regression analysis, Internet Media Effects (X3) has a direct relationship to the Participation of Young Voters (Y), where $\beta 3$ is 0.435 . That means that the use of 
Internet Media such as websites, news portals or websites, Blogs, Youtube, Facebook, Twitter, LINE, WhatsApp (WA), and Instagram, contributes to increasing the participation of young voters in the city of Bandung.

Hypothesis testing The $t$ test on the above table reveals that tgrade $(4,413)>t_{\text {tabel }}$ $(1,984)$. With a confidence level of 95 percent $(\alpha=0.05)$, it has been decided that $\mathrm{H}_{0}$ was rejected and $\mathrm{H}_{1}$ was accepted. Where $\mathrm{H}_{1}$ : There is a significant effect of the internet media on the participation of young voters in the city of Bandung. The significant influence shows that the influence caused by the effect of the internet media on the participation of young voters did not just happen by accident, rather, the internet media plays a role.

The grade of the regression coefficient value of the Internet Media Effects is the highest compared to Print Media Effects and Electronic Media Effects. This is in line with the respondents' perceptions of Internet Media Effects (Table 2) with the highest score compared to Print Media Effects and Electronic Media Effects. That means that the effects of Internet Media have a higher influence than the Effects of Print Media and Electronic Media, either cognitive, affective, or behavioral.

Regarding this result, there are some possibilities that the author can explain the causes of the significant effect of internet media on the participation of young voters. First, Young people are very open to the advancement of media technology especially information technology, therefore young voters are very interested in internet media. Second, young people's curiosity is principally extended, while the flow of internet information is very diverse and unlimited, which triggers their curiosity in using internet media. Third, the social media users demographically on average is the younger generation, so that the internet media at present is closely related to the lives of young people. Fourth, according to the research conducted by Loina Lalolo Krina Peranginangin and Munawaroh Zainal (2018), only a small number of young voter participants still get information from conventional media. It can be concluded that social media has been used widely and massively by the younger generation. Besides, social media is a source of political news and information for them. Fifth, most of the young people have already knowledge about the internet, according to the research by the Ministry of Information and Communication. Sixth, the internet media, in this case, social media, is very open as a forum to express thoughts, ideas, or opinions without being limited by the journalistic ethics (Wahid, 2018).

A study conducted by the Boston Consulting Group (BCG) in 2011 (KPPPA \& BPS, 2018) portrays on young people's interest in the media. Millennials in the United States have several characteristics. Firstly, the reading interest in a conventional way is decreasing, as they prefer to read by a smartphone. Secondly, there is somewhat compulsion for the millennials to have a social media account as a communication tool and information center. The Indonesian Economic Survey (SUSENAS) in 2017 reveals that the highest reason for the millennials in accessing the internet is to access social media (KPPPA \& BPS, 2018). Thirdly, Millennials prefer to use a smartphone rather than television, as anything can be found via mobile phones. The facts described here emphasize the similarity in the decline of young people's interest in conventional media such as print media and electronic media which occur not only in Indonesia. While the use of the internet is becoming the major media.

The research on the use of the internet particularly social media concerning the political participation of the public has been carried out recently. Whereas this study presents a comparison 
of types of media, namely print, electronic, and internet media in their influence on the participation of young voters contemporarily. It reveals that the use of media has changed, in which the use of print media and electronic media has decreased. While, the internet media is playing a major role compared to print and electronic media, as can be seen from the relationship and its effect on the participation of young voters.

\section{CONCLUSION}

This research is set to find out if there is a significant influence between the effects of print media, electronic media, and the internet media on the participation of young voters in the city of Bandung. The results illustrate that, first, newspapers and magazines (print media) did not significantly influence the participation of young voters in the City of Bandung. Second, radio and television (electronic media) do not significantly influence young voter participation in Bandung City. Third, the internet media such as websites, news sites or portals, Blogs, Youtube, Facebook, Twitter, LINE, WhatsApp (WA), and Instagram have a significant effect on the participation of young voter participation in the City of Bandung.

\section{BIBLIOGRAPHY}

Ardianto, E., Komala, L., \& Karlinah, S. (2007). Komunikasi Massa: Suatu Pengantar. Bandung: Simbiosa Rekatama Media.

Febriana, H. H., Nailufar, F. D., \& Subandi, H. (2015). Pengaruh Media Massa terhadap Pilihan Politik (Studi deskriptif terhadap Buruh dan Pegawai Negeri). Diunduh di https://www.academia.edu/12252182/PEN GARUH_MEDIA_MASSA_TERHADAP_PILIHA N_POLITIK_STUDI_DESKRIPSI_TERHADAP_B URUH_DAN_PEGAWAI_NEGERI_SIPIL_KOTA_ MALANG_PADA_PEMILU_PRESIDEN_2014_ tanggal 02 Januari 2019.
Firmanzah. (2012). Marketing Politik. Antara Pemahaman dan Realitas. Jakarta: Yayasan Obor Indonesia.

International IDEA. (2016). Voter Turnout Trend Around the World. Stockholm: International IDEA.

KPPPA \& BPS. (2018). Statistik Gender Tematik: Profil Generasi Milenial Indonesia. Jakarta: KPPPA.

KOMINFO. (2014). Riset Kominfo dan UNICEF Mengenai Perilaku Anak dan Remaja dalam Menggunakan Internet. Diunduh di <https://kominfo.go.id/content/detail/3834 /siaran-pers-no-17pihkominfo 22014tentang-riset-kominfo-dan-unicef-mengenaiperilaku-anak-dan-remaja-dalammenggunakan-internet/0/siaran__ pers $>$ tanggal 09 Januari 2019

KPU. (2017). Penyelenggaraan Pilkada Serentak 2015 dan 2017. Jakarta: KPU.

KPU Provinsi Jawa Barat. (2018). Laporan Penyelenggaraan Pemilihan Gubernur dan Wakil Gubernur Jawa Barat Tahun 2018. Bandung: KPU Provinsi Jawa Barat.

KPU Provinsi Jawa Barat. (2019). Laporan Penyelenggaraan Pemilihan Umum Tahun 2019. Bandung: KPU Provinsi Jawa Barat.

Nimmo, D. (2006). Komunikasi Politik. Bandung: PT. Remaja Rosdakarya.

Perangin-angin, L. K., \& Zainal, M. (2018). Partisipasi Politik Pemilih Pemula dalam Bingkai Jejaring Sosial di Media Sosial. Jurnal ASPIKOM. Volume 3 Nomor 4: 737-754.

Putra, A., Susanti, C. D., Yusari, I., Silitonga, I., \& Amrie, M. H. (2014). Politik Pemilih Muda Partisipasi Politik Anak Muda di Pekanbaru, Jakarta, Cirebon, Palu, dan Jayapura. Jakarta: Demos.

Rush, M., \& Althoff, P. (2013). Pengantar Sosiologi Politik. (K. Kartono, Trans.) Jakarta: Rajawali Pers.

Seven Ads. (2019). Potensi dan Demand Influencer Marketing di Indonesia. Diunduh di <https://www.sevenads.id/potensi-dandemand-influencer-marketing-diIndonesia/> tanggal 03 Desember 2019

Sugiyono. (2013). Statistika untuk Penelitian. Bandung: Alfabeta.

Surbakti, R. (2013). Memahami Ilmu Politik. Jakarta: Grasindo.

Wahid, U. (2018). Komunikasi Politik: Teori, Konsep, dan Aplikasi pada Era Media Baru. Bandung: Simbiosa Rekatama Media. 